\title{
The Environment in Southeast Asia: Injustice, Conflict and Activism
}

\author{
Adam Simpson
}

\section{Introduction}

As demonstrated throughout this volume, the types and severity of dilemmas facing states within Southeast Asia can vary enormously depending on their history, culture, politics and level of social and economic development. This is partially true of environmental issues, but many environmental concerns fail to respect the otherwise tangible privileges of economic development, just as they often ignore state boundaries. This situation was amply demonstrated by the choking haze - the worst ever - from primarily Indonesian forest fires engulfing Singapore and other countries in late 2015, and severely interrupting the otherwise largely First World daily existence of its citizens.

Transboundary environmental issues are often focused on mainland Southeast Asia, with the sharing of water resources from transboundary rivers a key example (Boer et al. 2016), but the haze covering most of the region clearly demonstrated that oceans are also no barrier to the transit of environmental problems. Similarly, climate change is likely to be the dominant overarching environmental issue for the foreseeable future and in this case regional, and even global, transboundary environmental pollution affects both mainland and maritime Southeast Asia equally. Southeast Asia is particularly at risk to weather extremes exacerbated by climate change; it includes four out of the ten countries globally most affected by extreme weather events between 1993 and 2012 (Kreft and Eckstein 2013).

'The environment' is, however, a social and political construct, the meaning of which is contested by competing interests within societies. In many parts of Southeast Asia 'the environment' has been conflated with 'natural resources', to be exploited; but the benefits are extracted by the 
privileged few while pollution and other related negative environmental externalities affect the less powerful. The environment in Southeast Asia is therefore inextricably linked to issues of justice, inequality and resultant social activism. The study of 'the environment' is clearly far more than simply ecological concerns. As Hirsch (2017: 3) notes, 'the environment is firmly embedded in the wider social, economic and political dynamics of the region as a whole and of its constituent countries'. More generally, within environmental movements 'issues of social democracy (participatory and representative), nonviolence, social equity and justice as well as ecology' influence activist agendas (Doyle et al. 2016: 20). Throughout the South, livelihood issues tend to dominate environmental movements. Southeast Asia, with its diversity of economic development, is home to a variety of emerging and established environmental movements including both livelihood-focused movements and those that have adopted broader social and political values, but environmental justice has emerged as a unifying theme.

While some authors see the region's entrenched authoritarianism as a potentially viable route to solving environmental issues (Beeson 2010), others argue that environmental movements and associated democratic modes of governance offer a better route for sustainable environmental protection (Shahar 2015). In general, however, the evidence tends to suggest that democratic regimes result in better environmental policies than the alternative (Fredriksson and Wollscheid 2007).

Environmental movements improve environmental outcomes in most settings but this is particularly salient in Southeast Asia. Despite a general historical trend towards democratization throughout the region the perspectives of dominant interests within society still tend to prevail. Environmental policy and values, even if expressed in policy statements or documents, often translate into little action on the ground due to vested interests undermining environmental policy objectives at the local, national or regional levels. The limitations of effective governance by ASEAN, the regional grouping, whether by design or in practice, exacerbate these issues.

Crucial, therefore, to addressing environmental issues in Southeast Asia is the role of environmental activists in formal and informal policymaking settings and other related elements of democratic governance, such as a free press. Authoritarian tendencies within the region are closely linked to extreme and widespread inequality with vested business interests creating structural impediments to wealth redistribution and democratic reform: Myanmar's recent turn towards more democratic rule in 2016 is heavily circumscribed by the military through constitutional limits and the enormous wealth accumulated by military enterprises and their associated cronies; Thailand, its traditionally more democratic neighbour where 0.1 per cent of the population owns 46.5 per cent of its assets according to the country's National Economics and Social Development Board, returned to overt authoritarian military rule in May 2014 and has crushed all forms of 
dissent by journalists and civil society while abandoning regulations on the construction of power plants and factories (22 January 2016, Prachatai). The economic activities of elites throughout the region are largely inimical to the protection of environmental values and limits on democratic forces ensure environmental critiques remain marginalized. Despite commitments from ASEAN to better engage civil society it is clear that the process is designed to improve its image and legitimacy rather than allowing any contestation of policy (Gerard 2014).

Indeed, state intrusions eviscerating the main independent ASEAN-wide activist grouping, the ASEAN Civil Society Conference (Gerard 2013), indicate that more informal networks and coalitions that avoid the ASEAN nomenclature altogether may provide more fertile grounds for developing broad-based and influential environmental movements promoting more sustainable and equitable forms of development in the region.

Within the environment movements of Southeast Asia the frames of post-colonialism and post-structuralism usually dominate, as opposed to those of post-materialism found predominantly in the United States and Australia and post-industrialism in Europe (Catney and Doyle 2011). Nevertheless, although much of the green intellectual development has occurred in the West, many green philosophies have been adapted within existing activist approaches in Southeast Asia focused on justice, livelihoods and environmental protection. Struggles for environmental justice are often fought in the context of a 'postcolonial state, [that] like its colonial precursor ... has been consistently willing to sacrifice both the environment and the poor to a longer-term vision of commercial growth and industrial modernity' (Williams and Mawdsley 2006: 662). As a result environmentalism 'often has its base in the livelihood struggles of the rural poor rather than the aesthetics of emerging middle classes' (Hirsch 1997: 4).

Although environmental campaigns are often conflicts over who should use and benefit from natural resources, the struggles are also more complex and played out over issues of 'interests, knowledge, values and meanings in local as well as national and global arenas' (Dwivedi 2001: 238). Despite a multiplicity of issues that are contested, in Southeast Asia 'the politics of environment have crystallised most clearly around large-scale resource projects, particularly those that involve appropriation of the local resource base by interests of state, capital, and dominant social groups in the name of national development' (Hirsch 1998: 55). This often results in campaigns against land grabbing, large dams and other energy projects, promoting local forms of environmental security focused on justice (Floyd and Matthew 2013; Simpson 2017).

To consider how the environment impacts on Southeast Asia, and how Southeast Asia impacts on the environment, this chapter examines some of the key environmental issues currently facing Southeast Asia. It begins with an exploration of the regional haze as a key transboundary dilemma using political economy analysis to explain the lack of effective action in 
addressing the issue, despite efforts over several decades. Deforestation is a key element of the haze and it is then discussed more broadly, particularly in the context of land grabs against indigenous or peasant forest dwellers. Deforestation and the haze also contribute to, and are impacted by the next topic examined, climate change, the most significant long-term environmental issue facing Southeast Asia, which is likely to exacerbate climate-related disasters in the future. The chapter then explores issues of energy security, which is also intimately related to climate change; the final section examines the related pursuit of hydropower through the building of large dams threatening the health of rivers, which also results in international conflict. Each section also examines the environmental movements that each issue has stimulated, which challenge the pervasive development focus on large-scale projects and unsustainable economic activity throughout the region (Smits 2015).

\section{The haze: An intractable regional issue}

In the second half of 2015 a thick pall of haze covered much of Southeast Asia. In late June it started in Indonesia, especially the islands of Sumatra and Kalimantan, and by September it had spread to Brunei, Cambodia, Malaysia, the Philippines, Singapore, southern Thailand and Vietnam. It was caused by forest fires on the Indonesian islands and continued until heavy rains in late October dowsed the flames and improved air quality. Just prior to the rains the Pollutant Standards Index (PSI) in Central Kalimantan hit a record high of 3,300. More than 136,000 respiratory illnesses were reported. The Indonesian government estimated that the haze crisis would cost it up to 475 trillion rupiahs (US $\$ 47$ billion) to mitigate (11 October 2015, The Straits Times), although the calculations to achieve the figure were not explained. Nevertheless, the previous worst regional haze event was in 1997-98 when the entire regional cost was estimated at US $\$ 9$ billion. In the end over 43 million people were affected, leading Indonesia's National Disaster Mitigation Agency (BNPB) to note that since '99 percent' of the fires were lit intentionally it had resulted in a 'crime against humanity of extraordinary proportions' (24 October 2015, Jakarta Globe). A later report by Harvard and Columbia University scholars estimated that the 2015 haze resulted in over 100,000 'excess deaths' across Indonesia, Malaysia and Singapore (Koplitz et al. 2016).

At the 11th Meeting of the Conference of the Parties to the ASEAN Agreement on Transboundary Haze Pollution (2003) in Hanoi, Vietnam, held in October 2015 just after the peak of the haze, the Environment Ministers from ASEAN member states expressed their concern over the 'unprecedented severity and geographical spread' of the smoke haze with their communal statement reading: 'The Ministers are committed to develop an ASEAN Haze-Free Roadmap which is an action-oriented and time-bound 
framework for ASEAN Member States to achieve the vision of Haze-Free ASEAN by 2020' (29 October 2015, Channel NewsAsia). Unfortunately, these statements have come and gone with little progress made; the ASEAN Agreement itself was preceded by the Regional Haze Action Plan endorsed by the Environment Ministers in 1997. ASEAN's own Haze Action Online website trumpets the more recent Agreement:

The Agreement is the first regional arrangement in the world that binds a group of contiguous states to tackle transboundary haze pollution resulting from land and forest fires. It has also been considered as a global role model for the tackling of transboundary issues. (ASEAN 2015)

If anything, however, the problem has got worse, with 2013 resulting in record high air pollution in Singapore and 2015 resulting in possibly the worst regional haze in history. The haze of 2016 was not as severe as the previous year but a state of emergency was still declared in six Indonesian provinces (25 August 2016, The Jakarta Post).

The haze is the result of the conversion of Indonesian forests and peatland into plantation agriculture using fire. This practice has occurred on an industrial scale since the 1980s, with oil palm plantations driving approximately 142,000 hectares of deforestation per annum, mostly by fire, since the turn of the millennium. Varkkey (2016) argues that economic regionalization of the Southeast Asian oil palm sector has been a major driver of the transboundary haze and that vested interests in the sector across the region have resulted in the failure of ASEANs haze-mitigation efforts. Similarly, in their political economy analysis of the haze, Hameiri and Jones (2015) argue that there are two aspects of Indonesia's domestic political environment that are crucial for understanding the outcomes in this issue: the political economy of the forestry and plantation sectors, and government decentralization since the late 1990s.

If land is heavily forested, forestry operators can log the land for profit. After logging, or if the land is peat, plantation operators can clear it cheaply through the use of fire. The palm oil sector is now one of Indonesia's most powerful industries with up to 8 million people employed or benefiting either directly or indirectly, assisting the country's poverty reduction goals. The government therefore has ambitious expansion plans for the industry. Market-based reforms since the 1990s have also squeezed profits for smallholder farms, concentrating land and the palm oil business in larger state-linked companies, unlike the sector in Thailand, which is dominated by smallholders. Following the Asian financial crisis several large Indonesian agribusinesses went bankrupt and IMF-enforced reforms opened up the sector to full foreign ownership. This facilitated large land acquisitions by state-backed Singaporean and Malaysian companies that now control up to two-thirds of Indonesian plantations. Patronage ties between the 
companies and ruling regimes back home have been replicated in Indonesia, diluting any attempts at rigorous governance.

Political decentralization in Indonesia since the 1990s has exacerbated these difficulties and enabled new collusive relationships between these larger plantation firms and district-level governments, which entrenches resistance to any central government attempts to reduce the fires. As a result of these two factors, 'although Malaysia and Singapore are the primary "victims" of transboundary haze pollution, powerful interests based there are also among its primary drivers' (Hameiri and Jones 2015: 106).

This political economy analysis demonstrates the crucial role that environmental movements and civil society more broadly have in highlighting corporate-related corruption and patronage as well as environmental destruction. One example of local environmental organizations forming a forest protection coalition, a crucial strategy for pooling limited resources (Yanacopulos 2005), is Eyes on the Forest (EoF) in Riau, Sumatra comprised of Jikalahari (Forest Rescue Network Riau), Walhi Riau (Friends of the Earth Indonesia) and WWF Indonesia's Tesso Nilo Programme (Eyes on the Forest 2016). The organization provides satellite imagery of forests to undermine corporations' protestations of innocence while investigating the deep connections between companies and politics.

\section{Deforestation}

The haze is one symptom, albeit the most visible, of oil palm-related deforestation across the region, but degradation of forests takes many other forms with similar associated environmental impacts. Degradation of forests can occur through poor mining practices, which often entails clear felling of surrounding forests, resulting in the drying out of temperate or sub-tropical forests and increased susceptibility to fire. In areas of high rainfall partial deforestation can exacerbate erosion and cause river pollution. A thriving trade in wildlife and other non-timber forest products, much of it illegal, has depleted non-timber forest resources in many Southeast Asian countries. These processes can have a devastating impact on the rich biodiversity of Southeast Asia's forests. The region now has the highest proportion of threatened species of vascular plants, reptiles, birds and mammals (Seymour and Kanowski 2017). The widespread development of plantations across the region has resulted in several countries, including Thailand, the Philippines and Vietnam, showing recent gains in tree cover with 25 per cent of Vietnam's forest cover now human-induced. Plantations and other planted forests cannot compete, however, with natural forests for biodiversity conservation or the provision of other ecosystem services, particularly carbon storage.

Between 2001 and 2010 Southeast Asia's annual deforestation rate of 0.5 per cent was the highest among tropical regions, translating into a loss 
of about a million hectares of forest cover per year. By 2010, forest cover had fallen to less than half of total land area in the region, corresponding to a reduction of about 16 per cent since 1990 (Food and Agriculture Organization 2011). Recent research suggests that natural forest depletion continues in all countries in the region in this period, and in some cases at increasing rates compared to the first decade (Seymour and Kanowski 2017). Data on aggregate regional forest cover change masks large variations within and between countries and across forest types. Mangrove forests are particularly vulnerable, disappearing almost twice as fast as other forest types (Food and Agriculture Organization 2011). These forests are particularly useful as barriers to ocean surges caused by either storms and cyclones (called typhoons in the north-western Pacific Ocean) or earthquakes and tsunamis, by which the region has been severely affected. Inland deforestation results in erosion and often fatal landslides.

The Global Forest Resources Assessment 2015 is the most recent authoritative account of the state of the world's forests (Food and Agriculture Organization 2015). It reports a decrease in natural forest area in the period 2011-2015 in Cambodia, Indonesia, Malaysia and Myanmar with no change in the Philippines and an increase in Lao PDR and Vietnam. Given the opaque authoritarian nature of these last two regimes and the rapacious nature of China-backed development in both countries, it seems somewhat unlikely that these reported increases actually exist. Even though the 2015 Assessment is the most accurate to date there are still significant problems in Southeast Asia with measuring different types of land that is forested, partially forested, agricultural or covered with multiple-use forests. In Indonesia, for instance, a much more democratic country than Vietnam or Lao PDR which hosts the region's largest extent of area designated as forest, much land officially designated as forest has been illegally converted to agriculture, but remains designated as forest. This discrepancy reflects tensions between the central forest administration seeking to retain influence over the forest estate and decentralized administrative bodies seeking greater opportunities to allocate land for agricultural development (Sloan and Sayer 2015: 136).

Outside of Papua New Guinea, where customary rights are constitutionally protected, most heavily forested countries in Southeast Asia allocate most forests to the state, which sees them then zoned for exploitation or, often ineffectively, for protection, depriving indigenous communities of access and traditional ownership. Deforestation is therefore intimately tied up with land confiscation or land grabbing. All land use and access requires exclusion of some kind but it far too often results in dispossession of the marginalized or indigenous (Hall et al. 2011). Despite inequalities of power and often unjust outcomes land grabbing has also become a site of resistance for social counter-movements against the forces of corporate power (Edelman et al. 2013; Margulis et al. 2013). Activism by indigenous groups, peasant farmers and their supporters has become a global 
movement culminating in the UN Declaration on the Rights of Indigenous Peoples (United Nations 2008).

Local groups within Southeast Asia, such as Tebtebba (Indigenous Peoples' International Centre for Policy Research and Education) in the Philippines argue that indigenous ownership and control of land are essential not just to promote equitable development, but to halt deforestation and address the issue of climate change. Tebtebba, in conjunction with the Washington-based Rights and Resources Initiative, wrote a report arguing that the funds allocated to the UN and World Bank-supported REDD+ carbon market would provide indigenous peoples with secure tenure to 450 million hectares of land, an area almost half the size of Europe (Rights and Resources Initiative and Tebtebba 2014). They argue that indigenous land tenure is a far more effective, and just, way to deal with climate change, which is likely to be the most important environmental issue in the region for the foreseeable future.

\section{Climate change and natural disasters}

While Southeast Asia faces a plethora of environmental issues, in the long term the impacts of global climate change are likely to significantly exacerbate existing environmental insecurities. Climate change is likely to result in more extremes in cold, and particularly heat, affecting regional weather and climate patterns in Southeast Asia. Much of the region is low lying, coastal or otherwise susceptible to weather extremes such as cyclones that are likely to be exacerbated in frequency and intensity by climate change as water temperatures increase. The ten countries globally most affected by extreme weather events between 1993 and 2012 included four countries from Southeast Asia: Myanmar, Thailand, the Philippines and Vietnam (Kreft and Eckstein 2013). The most devastating potential impacts of climate change will affect different geographical areas of the South in different ways, with Africa's mortality and economic loss risk largely due to drought while the impacts on Southeast Asia derive from a multitude of climate-related disasters including droughts, landslides, floods and tropical cyclones (Webersik 2010: 85).

Although it is primarily forest fires that cause haze across the region, weather and climate change can mitigate or exacerbate the impacts. The worst forest fires until recently occurred in 1997, which coincided with the extreme El Niño weather system in 1997-98 that resulted in the world experiencing its highest temperatures since the industrial revolution. The El Niño system creates hot, dry weather in the western Pacific Ocean and across Southeast Asia, exacerbating forest fires and the resulting haze. The calamitous forest fires in the second half of 2015 coincided with the biggest El Niño since 1997-98 (ESCAP 2015) and the hottest year on record at that time, superseding 2014 (World Meteorological Organization 2016); 
globally, 2016 was even hotter, about 1.1 degrees above the pre-industrial era (World Meteorological Organization 2017).

These climate change impacts are occurring despite the relatively insignificant historical contribution to climate change that some ASEAN countries have made. While there is no doubt that in recent years countries such as Indonesia have made substantial contributions to greenhouse gases through the deforestation outlined above, the estimated per capita emissions between 1960 and 2005 for Cambodia and Laos were approximately 3 tons of $\mathrm{CO}_{2}$ while for China it was 68, Australia 496 and the United States 720 (Biel and Muffett 2009: 10-12). Historical figures are not available for Myanmar but as a country of 50 million people at a comparable stage of development to Cambodia and Laos it, too, is likely to have made a minimal contribution (Simpson 2018).

While there are clearly global aspects of climate justice, between states, there are numerous local incidences of unequal impacts and responses to climate change that reflect the social, political and economic inequalities within states (Harris 2010). In Southeast Asia the persistence of authoritarianism and attendant gross inequality has resulted in particularly pernicious examples of this injustice. In Laos, one of the poorest countries of Southeast Asia, the authoritarian government has been enthusiastic at resettling highland communities of shifting cultivators to lowland environments in long-standing attempts at removal of shifting cultivation as a practice and its attendant culture (Baird and Shoemaker 2007).

In northern Laos, in a village in Luang Prabang's Phonexay District with a mix of Khmu and Hmong households, resettlement exposed households to the climate-related hazard of flooding. Government interventions to support resettlement had the effect of diminishing the ability of households to adapt to their new living contexts. They arrived at their lowland location in the late 1980s. They had farms and gardens located in the lowlands, near a river. For the first time since settling in the village, exceptional flooding and associated landslides occurred in 2010, 2011 and 2013 (Salamanca and Rigg 2017). The flooding was likely the result of a combination of local deforestation, badly designed infrastructure developments in the village and climate change - all of which the village had limited control over due to their marginalized political, cultural and economic position within an authoritarian governance structure. Their ability to adapt to climate change and respond to the flooding was also limited due to the limited land endowments of the villagers, the lack of fallow land - due to government decree - resulting in trees being replaced with corn, sesame and other annual crops, which are poor at absorbing runoff, and conflicts over land entitlement with influential absentee farmers who were more easily able to secure their tenure.

Similarly, the floods of late 2011 that inundated most of central Thailand, the worst in fifty years, clearly demonstrated that some sectors and people are more important than others. Climate change has resulted in 
substantially increased pre-monsoon rainfall in the Chao Phraya River Basin in recent decades and a significant sea level rise at the river outlet; both factors increased the severity of the 2011 floods, which resulted in more than 800 deaths and affected 13.6 million people (Parichart Promchote et al. 2016). Although many parts of Thailand experienced this flooding, not all communities or people were affected or treated equally. The management of floods and other disasters in Thailand has been organized by elites and their bureaucracies to be deployed in ways that serve their interests and not those of more politically marginalized groups. This was particularly evident in the 2011 floods where privileged areas of the industrial sector and the associated Thai elites' assets were protected while other, less fortunate areas with fewer political connections, were sacrificed (Lebel et al. 2011; Salamanca and Rigg 2017).

The Philippines is another country that is highly susceptible to climate-induced risks, particularly cyclones. In both 2012 and 2013 devastating cyclones hit Southeast Asia and the Philippines in particular. As an archipelago nation the Philippines is densely populated with long coastlines. In December 2012 the Philippines was hit by Typhoon Bopha, which claimed over 1,400 deaths and in November 2013 Typhoon Haiyan (Yolanda), one of the strongest tropical cyclones ever recorded, killed at least 6,300 people. Although it is not possible to ascribe climate change as the cause of any single weather event, these cyclones are likely to increase in frequency and intensity as the ocean temperatures rise.

While the Philippines is regularly plagued by cyclones the most devastating cyclone of the region in recent times was Cyclone Nargis in May 2008, which caused the worst recorded natural disaster in Myanmar's history. It devastated the Ayeyarwady (Irrawaddy) Delta region and caused at least 140,000 deaths, destroyed 800,000 houses and left millions of Ayeyarwady Delta residents, mostly from the Kayin (Karen) ethnic minority, homeless and facing disease and malnutrition; many people died in the days following the cyclone due to a lack of food, potable water and shelter. When it reached Category 4 it became the first time that a Category 4 storm had formed in three consecutive years in the North Indian Ocean Basin. Myanmar was still ruled by a military junta at the time, whose first response was to hold up visa applications for foreign aid workers and journalists and to deny entry to Western aid deliveries, leading to a massive build-up of food, medicine and disaster response expertise in Bangkok in the crucial days following the event (Paik 2011; Vicary 2010). These actions compounded the environmental insecurities already inflicted by the military through extensive coastal mangrove destruction, fuelled by the growth of military shrimp and fish farms, resulting in greater flooding and devastation along the cyclone's path than would otherwise be the case. In the aftermath of the cyclone the ASEAN secretary-general blamed extensive mangrove destruction, and the resultant removal of the natural barrier, for the enormous death toll in Myanmar (Simpson 2015b). In contrast with 
the excess water associated with Cyclone Nargis, much of Southeast Asia is threatened with increased food and water insecurity due to changing monsoonal rain patterns causing drought in areas such as Myanmar's central dry zone (UNDP 2011; Asian Development Bank 2012).

Despite the appalling human suffering caused by Cyclone Nargis it did eventually result in the first genuine attempt at an ASEAN-wide coordinated disaster response. ASEAN, together with the Myanmar government, the UN and other international agencies, formed the Post-Nargis Joint Assessment team, which was formed to coordinate, facilitate and monitor the distribution of aid and the assessment of recovery needs (Roberts 2010: 192-194). Historically, issues of climate change adaptation have hardly been considered in many ASEAN countries (Francisco 2008: 10-11) but Cyclone Nargis provided an opportunity for ASEAN to tighten its regional cooperation for the type of disaster response that is likely to be increasingly required as the impacts of climate change worsen (Pelling 2011: 84-85).

Nevertheless, broader climate change action by ASEAN has been limited. At the 3rd East Asia Summit (EAS) in Singapore in November 2007 Australia, China, India, Japan, South Korea, New Zealand and the member countries of ASEAN signed the Singapore Declaration on Climate Change, Energy and the Environment. Apart from the 'EAS-wide aspirational goal of increasing cumulative forest cover in the region by at least 15 million hectares ... by 2020' the Declaration focused primarily on values and processes and avoided fixing targets for climate change and energy, instead simply committing 'to the common goal of stabilising atmospheric greenhouse gas concentrations in the long run' (East Asia Summit 2007). An ASEAN Action Plan on Joint Response to Climate Change was adopted by the 12th ASEAN Ministerial Meeting on Environment held in September 2012 in Bangkok (ASEAN 2012), but the energy policies of individual countries within the region indicate that there are few serious attempts to address the issue. Since the early 1990s Thailand has had one of the most progressive renewable energy policies in the region, with a liberalized and diverse energy sector, but these gains have been steadily eroded in recent years, first by the populist Yingluck Shinawatra government and then further by the authoritarian military regime since 2014 (Simpson and Smits 2017).

As the inability to address the regional haze has demonstrated, vested interests in all countries, in conjunction with elements of authoritarian governance, have meant that productive negotiations on climate change and, indeed, any of Southeast Asia's significant environmental problems within ASEAN have proved difficult. There is evidence that more democratic regimes set stricter environmental policies than autocracies (Fredriksson and Wollscheid 2007), so it is not surprising that environmental concerns do not rate highly on the agendas of ASEAN governments. As Beeson (2009: 339) notes with regards to environmental policy, 'it is hard to overstate the size of the challenge or the feebleness of the response thus far in Southeast Asia'. 
Climate change has become the primary environmental issue and it is noteworthy that environmental groups have such little formal influence throughout Southeast Asia. While deliberative forms of environmental policymaking are crucial for addressing a problem as complex and as integrated into economic concerns as climate change (Stevenson and Dryzek 2014), deliberative decision-making is virtually absent in Southeast Asia (Beeson 2010). Apart from the many indigenous rights or forest groups in the region, who are generally excluded from formal discussions, there are some specifically climate-oriented groups who have made attempts to integrate policymaking and activism. 350 Singapore, a regional affiliate to 350 .org, has convened a series of conferences to address climate change, including ASEAN Power Shift 2015, held in July of that year in the lead-up to COP21 of the UN Framework on Climate Change (UNFCCC) in Paris, which was supported by various environmental ministries throughout ASEAN (350 Singapore 2015). It is clear, however, that environmental ministries throughout the region hold little sway over economic policy in general, and energy policy in particular, and while the pursuit of energy security and short-term economic gain are prioritized by Southeast Asian governments, sustainable solutions to the threat of climate change will be lacking.

\section{Energy security}

Energy plays a crucial role in the operation of all modern economies and it is likewise central to the problems, and solutions, that surround climate change. Replacing the burning of fossil fuels with renewable and less carbon-intensive technologies is a crucial element in the necessary shift that societies must make if calamitous climate change is to be avoided. In December 2015, at COP21 in Paris, the Commission on Human Rights in the Philippines announced that it would launch an investigation into the top-50 big polluters, which could hold fossil fuel companies such as Exxon Mobil responsible for the impacts of climate change, such as extreme weather events (13 December 2015, Inquirer.net). The investigation will be held in response to a complaint brought by survivors of Typhoons Haiyan and Bopha and justice-focused environmental groups such as the Philippine Movement for Climate Justice, Greenpeace Southeast Asia and the Philippine Alliance of Human Rights Advocates. Although this will be the world's first national human rights investigation of its kind, it was announced just weeks after the New York attorney general opened a similar investigation into ExxonMobil for knowing about the risks of climate change as early as 1970s and keeping it from the public and investors, using strategies that are remarkably similar to tobacco companies who denied the health costs of smoking (Oreskes and Conway 2010; Greenpeace Southeast Asia 2016).

It is clear that there is a growing global movement to address climate change, and particularly the nefarious strategies of corporations to 
undermine shifts away from fossil fuels but throughout Southeast Asia these types of Human Rights Commissions are relatively powerless in the face of Southeast Asian corporate elites and their allies. The corrupt influence of authoritarian fossil fuel interests in the region was on display soon after the Commission's announcement when Malaysia's attorney general found that a US\$681 million 'donation' by Saudi Arabia's royal family into Prime Minister Najib Razak's personal bank account before the closely contested 2013 general election was not illegal; he ordered Malaysia's anti-corruption body to close its investigation into the transfers (26 January 2016, Wall Street Journal).

Similarly, although international financial institutions (IFIs) such as the Asian Development Bank (ADB) and World Bank have made some steps towards limiting their climate impact, they and ASEAN governments remain wedded to financing large-scale energy projects that are still highly environmentally destructive. The ADB, for instance, finances small renewable energy projects with limited environmental impact that can be highlighted in their marketing but this financing is dwarfed by the bulk of the spending on more destructive projects. In the Vientiane Plan of Action for Greater Mekong Subregion (GMS) Development there are several relatively small measures such as the 'Promotion of Rural Renewable Energy and Cleaner Production' (renamed GMS Climate-Friendly Bioenergy Project) which cost $\$ 1$ million or less (Greater Mekong Subregion 2010). On the other hand there are hydroelectric dams which receive hundreds of millions of dollars which the ADB claims are climate-friendly projects but which are likely to cause long-term food and water security issues that will be left to future generations to deal with (HSAF 2010).

Similarly, natural gas is considered relatively climate-friendly and ASEAN has pointed to its Trans-ASEAN Gas Pipeline Infrastructure Project (TAGP) as a climate-friendly energy development promoting energy security. The Yadana and Yetagun gas pipelines that carried gas from Myanmar to Thailand, completed in 1999, were the first instalments of this project and resulted in adverse human and environmental security outcomes for local communities, particularly on the Myanmar side of the border (Sovacool 2009; Simpson 2017). Other projects, such as the Thai-Malaysian Gas Pipeline, may not have had quite the adverse social outcomes, under more democratic regimes at that stage, but the wishes of local communities were still ignored in its development (Simpson 2015a).

Although there are currently no commercial nuclear facilities in ASEAN, there are significant plans by Vietnam, Indonesia and Thailand to develop nuclear power as a climate-friendly energy source. The Singapore Declaration identified cooperation 'for the development and use of civilian nuclear power' as a 'cleaner energy' based on the earlier Cebu Declaration on East Asian Energy Security (East Asia Summit 2007). Although nuclear energy emits fewer greenhouse gases than coal-fired power stations, the nuclear cycle still emits large amounts of $\mathrm{CO}_{2}$ with the mining, milling, leeching, 
enriching and reprocessing of uranium all requiring large amounts of electricity often generated, particularly in Southeast Asia, from coal-fired power stations. Plant construction and decommissioning also generate substantial amounts of greenhouse gases (Sovacool 2010: 379).

The role of corporate interests and the perpetuating of a broadly neo-liberal approach to both the impacts and responses to climate change within international fora have necessitated the promotion of largely technological and market-driven responses to climate change in both the North and South (Chaturvedi and Doyle 2015). Business interests are not, however, monolithic and there is a diversity of business interests that react to climate change in different ways (Faulkner 2009: 97-100). Nevertheless, the relatively small commitment by IFIs to small-scale community-oriented projects compared with the large-scale dams that they continue to fund throughout Southeast Asia demonstrates that modes of energy generation that destroy river ecosystems and communities are likely to persist (Smits 2015).

\section{Rivers and dams}

One of the most important transboundary environmental issues in mainland Southeast Asia is that of river use and health. Most of Southeast Asia lies in the tropical zone and depends on monsoonal rains for agriculture; in the dry season it is largely dependent on rivers for irrigation, water and food. These rivers are increasingly seen as easy, and climate-friendly, sources of energy, which therefore provides an issue with intersecting concerns over food, water and energy security (Floyd and Matthew 2013). Due to their dire social and environmental impacts, hydropower dams are therefore becoming the dominant project-centred environmental campaigns of the region. Justice or livelihood-focused environmental movements construe both domestic and transnational injustices and inequalities associated with these dams.

While marginalized ethnic or social groupings are often displaced or disadvantaged by the dams, the resultant electricity is often exported to more economically developed neighbouring countries. This has particularly been the case in Myanmar and Laos, with numerous large dams being built or planned and almost all the electricity being exported to Thailand and China (Simpson 2007, 2013). In military-ruled Myanmar, prior to the political reform process that began in 2011, dams were built without any public consultation or allowance for dissent, with local communities often losing livelihoods and food and water security while the electricity was either sold across the border or transmitted to military installations or associated crony businesses; displaced communities would not even have access to the electricity their traditional lands supplied. The political reform process has altered this dynamic and the new government in 2016 led by Aung San Suu 
Kyi may be more responsive to community needs, although the demands of civil society are likely to be much higher (Simpson 2018).

Although there are many hydropower-driven industrial developments underway across the region, such as the Sarawak Corridor of Renewable Energy in Malaysia (Sovacool and Cooper 2013), it is developments in the Mekong River Basin that are causing most regional concern. The Mekong River is the main transboundary watercourse in the region with a 795,000 $\mathrm{km}^{2}$ basin supporting 70 million people in China, Myanmar, Thailand, Laos, Cambodia and Vietnam. The river has been subjected to a series of dams in its upper reaches in China, where it is known as the Lancang River. Seven large dams have already been built, and over fourteen more are under construction or being planned in Yunnan, Tibet and Qinghai. Downriver in Laos there are twelve large hydropower dams (over 30MW) operating with a further eleven large hydropower dams under construction; over fifty more are either at an advanced stage of planning or at feasibility study stage (Middleton 2017).

Due to the complicity in the building of dams of the state-based Mekong River Commission (MRC) - whose membership comprises Cambodia, Laos, Thailand and Vietnam but excludes China - and its top-down method of governance, the immense justice issues associated with dams on the Mekong has created a vast sprawling activist network across the region, reflecting the transboundary nature of the river itself. The main Bangkok-based 'Save the Mekong Coalition' comprises local environment groups, as well as national and transnational NGOs, including Living River Siam, TERRA (Towards Ecological Recovery and Regional Alliance), Salween Watch, China Development Brief, EarthRights International, Probe International and International Rivers (Pichamon Yeophantong 2014).

Different countries in the Mekong Basin have different interests in relation to the river, with downstream countries concerned about upstream dams, and the diverse activist groups and also state and corporate interests have used a range of legal instruments, both domestic and international, to pursue their interests within the basin (Boer et al. 2016). Anti-dam groups campaigned against the World Bank and ADB funding large dams in the 1990s and were successful in suspending their support. The World Bank-supported World Commission of Dams produced a report in 2000 that set new standards for the building of dams (WCD 2000), and in 2005 the banks decided to approve funding for the Nam Theun 2 Dam on a tributary of the Mekong in Laos. Despite huge investments in social and environmental mitigation there were significant negative impacts on livelihood and ecology, both in the Nam Theun Basin itself and the neighbouring Xe Bang Fai River, where the hydroelectricty-producing water from the dam is diverted (Porter and Shivakumar 2011; Baird et al. 2015; Baird and Quastel 2015).

Although activists and scholars have been critical of the outcomes of the Nam Theun 2, this project now looks almost quaint compared with 
the dam-building activity currently underway. While the social and environmental safeguards of the World Bank and ADB have been criticized for lacking efficacy, they look rigorous compared with domestic environmental legislation throughout the region (Baird and Frankel 2015) and the Chinese-driven dam-building extravaganza now being pursued (Simpson and Park 2013). The backing of China has provided the support required by the government of Laos to ignore protestations from its downriver neighbours, Cambodia and Vietnam, and approve two mainstream dams, the Xayaburi and Don Sahong Dams, the latter provocatively sited less than two kilometres from the Laos-Cambodia border (Baird 2011; CarewReid 2017). These mainstream dams will have significant adverse impact on the ecology and health of the river and its already stretched fisheries resources (Bush and Marschke 2017).

\section{Conclusion}

It is clear that the future health of the environment in Southeast Asia is intimately connected with the health and well-being of its inhabitants. The climate is rapidly changing in the region, as it is in much of the world, and climate-induced disasters - either short-terms events, such as cyclones, or slow-burn disasters, such as droughts due to changing monsoonal rain patterns - are likely to have severe impacts on livelihoods and welfare across the region. As is the case elsewhere, climate change will make attempts to deal with other social and environmental issues much more difficult, and the poor and the marginalized will bear the brunt of the misfortune.

Most environmental concerns are intimately intertwined with both other environmental issues and their social, political and economic context. Feedback loops can either improve or worsen environmental outcomes: deforestation through fire causes the regional haze but also exacerbates climate change; climate change worsens the haze through a drier climate due to atmospheric warming and more severe El Niño events. Large hydropower dams may reduce the need for coal-fired power stations, but the reservoirs flood valuable forests and cause much higher evaporation rates as well as high levels of social dislocation and ecological damage.

It is clear, therefore, that addressing Southeast Asia's environmental issues requires a holistic approach to both the environment and society. Unfortunately, national governments and ASEAN have proven inept custodians of the region's natural resources, with vested corporate and elite interests combining with authoritarian governance to stymie environmentally responsible policymaking and implementation. While issues such as the haze, which are clearly discernible across the region, become front-page news it is largely due to the efforts of environmental activists that other, more physically remote or displaced, environmental issues become publicized and understood. Although they are repressed or restricted by most 
governments, it is only through the continued development of broad-based local, national and transnational environmental movements that Southeast Asia's societies are likely to adequately address the disparate and severe environmental crises facing the region.

\section{Further reading}

Boer, B., P. Hirsch, F. Johns, B. Saul and N. Scurrah (2016) The Mekong: A Socio-legal Approach to River Basin Development (London and New York, NY: Routledge).

Hirsch, P. (ed.) (2017) Routledge Handbook of the Environment in Southeast Asia (London and New York, NY: Routledge).

Varkkey, H. (2016) The Haze Problem in Southeast Asia: Palm Oil and Patronage (London and New York, NY: Routledge).

Walker, A. (2012) Thailand's Political Peasants: Power in the Modern Rural Economy (Madison, WI: The University of Wisconsin Press). 